NBER WORKING PAPER SERIES

\title{
THE CONSEQUENCES OF ENTREPRENEURIAL FINANCE: A REGRESSION DISCONTINUITY ANALYSIS
}

\author{
William R. Kerr \\ Josh Lerner \\ Antoinette Schoar \\ Working Paper 15831 \\ http://www.nber.org/papers/w15831 \\ NATIONAL BUREAU OF ECONOMIC RESEARCH \\ 1050 Massachusetts Avenue \\ Cambridge, MA 02138 \\ March 2010
}

We thank James Geshwiler of CommonAngels, Warren Hanselman and Richard Sudek of Tech Coast Angels, and John May of the Washington Dinner Club for their enthusiastic support of this project and willingness to share data. We also thank the many entrepreneurs who responded to our inquiries. Harvard Business School's Division of Research and the Kauffman Foundation supported this research. Andrei Cristea provided excellent research assistance. All errors and omissions are our own. The views expressed herein are those of the authors and do not necessarily reflect the views of the National Bureau of Economic Research.

NBER working papers are circulated for discussion and comment purposes. They have not been peerreviewed or been subject to the review by the NBER Board of Directors that accompanies official NBER publications.

(C) 2010 by William R. Kerr, Josh Lerner, and Antoinette Schoar. All rights reserved. Short sections of text, not to exceed two paragraphs, may be quoted without explicit permission provided that full credit, including $\odot$ notice, is given to the source. 
The Consequences of Entrepreneurial Finance: A Regression Discontinuity Analysis

William R. Kerr, Josh Lerner, and Antoinette Schoar

NBER Working Paper No. 15831

March 2010

JEL No. G24,L26,M13,O31,R51

\begin{abstract}
This paper documents the role of angel funding for the growth, survival, and access to follow-on funding of high-growth start-up firms. We use a regression discontinuity approach to control for unobserved heterogeneity between firms that obtain funding and those that do not. This technique exploits that a small change in the collective interest levels of the angels can lead to a discrete change in the probability of funding for otherwise comparable ventures. We first show that angel funding is positively correlated with higher survival, additional fundraising outside the angel group, and faster growth measured through growth in web site traffic. The improvements typically range between $30 \%$ and $50 \%$. When using the regression discontinuity approach, we still find a strong, positive effect of angel funding on the survival and growth of ventures, but not on access to additional financing. Overall, the results suggest that the bundle of inputs that angel investors provide have a large and significant impact on the success and survival of start-up ventures.
\end{abstract}

William R. Kerr

Harvard Business School

Rock Center 212

Soldiers Field

Boston, MA 02163

and NBER

wkerr@hbs.edu

Josh Lerner

Harvard Business School

Rock Center 214

Boston, MA 02163

and NBER

jlerner@hbs.edu
Antoinette Schoar

Sloan School of Management

50 Memorial Drive, E52-455

Cambridge, MA 02142

and NBER

aschoar@mit.edu 
One of the central and most enduring questions in the entrepreneurial finance literature is the extent to which early stage financiers such as angels or venture funds have a real impact on the firms in which they invest. An extensive theoretical literature suggests the combination of intensive monitoring, staged investments, and powerful control rights in these types of deals should alleviate agency problems between entrepreneurs and institutional investors (examples include Admati and Pfleiderer, 1994; Berglöf, 1994; Bergmann and Hege, 1998; Cornelli and Yosha, 2003; and Hellmann, 1998). This bundle of inputs, the works suggest, can lead to improved governance and operations in the portfolio firms, lower capital constraints, and ultimately stronger firm growth and performance.

But the empirical documentation of this claim has been challenging. Hellmann and Puri (2000) provide a first detailed comparison of the growth path of venture backed versus non venture backed firms. ${ }^{1}$ This approach, however, faces the natural challenge that unobserved heterogeneity across entrepreneurs, such as ability or ambition, might drive the growth path of the firms as well as the venture capitalists' decision to invest. These problems are particularly acute for evaluating early-stage investments. An alternative approach is to find exogenous shocks to the level of venture financing. Examples of such exogenous shocks are public policy changes (Kortum and Lerner, 2000), variations in endowment returns (Samila and Sorenson, 2010), and differences in state pension funding levels (Mollica and Zingales, 2007). These studies, however, can only examine the impact of entrepreneurial finance activity at an aggregate level. Given the very modest share that high-potential growth firms represent of all

\footnotetext{
${ }^{1}$ A similar approach is taken in Puri and Zarutskie (2008) and Chemmanur et al. (2009) who employ comprehensive Census Bureau records of private firms to form more detailed control groups based on observable characteristics.
} 
entrepreneurial ventures and economic activity overall, these studies face a "needle in the haystack" type challenge to detect any results.

This paper takes a fresh look at the question of whether entrepreneurial financiers affect the success and growth of new ventures. We focus on a neglected segment of entrepreneurial finance: angel investments. Angel investors have received much less attention than venture capitalists, despite the fact that some estimates suggest that these investors are as significant a force for high-potential start-up investments as venture capitalists, and even more significant investors elsewhere (Shane, 2008; Goldfarb et al., 2007; Sudek et al., 2008). Angel investors are increasingly structured as semi-formal networks of high net worth individuals, often former entrepreneurs themselves, who meet in regular intervals (usually once a month for breakfast or dinner) to hear aspiring entrepreneurs pitch their business plans. The angels then decide to conduct further due diligence and ultimately whether to invest in some of these deals either individually or in subgroups of the members. Similarly to traditional venture capital investments, angel investment groups often adopt a very hands-on role in the deals they get involved in and provide entrepreneurs with advice and contacts to potential business partners.

In addition to their inherent interest as funders of early stage companies, angel investment groups are distinguished from the majority of traditional venture capital organizations by the fact that they make their investment decisions through well documented collections of interest and, in some cases, formal votes. By way of contrast, the venture firms that we talked to all employ a consensual process, in which controversial proposals are withdrawn before coming up for a formal vote or disagreements are resolved in conversations before the actual voting takes place. In addition, venture firms also rarely document the detailed voting behind their decisions. Angel investors, in contrast, express their interest for deals independently from one another and based 
upon personal assessment. This allows us to observe the level of support or lack thereof for the different deals that come before the angel group.

These properties allow us to undertake a regression discontinuity design using data from two angel investment groups. This approach, while today widely used in program evaluations by economists (Lee and Lemieux, 2009), remains underutilized in financial economics (exceptions include Rauh, 2006; and Cherenko and Sunderam, 2009). We essentially compare firms that fall just above and those that are just below the criteria for funding for the angel group. The underlying identification relies on the idea that firms that fall just around the cut-off level have very similar ex ante characteristics that allow us to estimate the causal effect of obtaining angel financing. After showing the ex ante comparability of the ventures in the border region, we examine differences in their long-run performance. In this way, we can employ micro-data on firm outcomes while minimizing the problem of unobserved heterogeneity between the funded and rejected transactions.

Several clear patterns emerge from our analysis: First, and maybe not surprisingly, companies that elicit higher interest in initial voting at the angel meeting are far more likely to be ultimately funded by the angel groups. More importantly, angel groups display break points or discontinuities where a small change in the collective interest levels of the angels leads to a discrete change in the probability of funding among otherwise comparable ventures. This provides a powerful empirical foothold for overcoming quality differences and selection bias between funded and unfunded ventures.

Second, we look at the impact of angel funding on performance and access to follow-on financing for firms that received angel funding compared to those that did not. We first compare the outcomes for the full sample of firms that pitched to the angels and then narrow our 
identification strategy to the firms that fall just above and below the funding breakpoint we identified. We show that funded firms are significantly more like to survive for at least four years (or until 2010) and to raise additional financing outside the angel group. They are also more likely to show improved venture performance and growth as measured through growth in web site traffic and web site rankings. The improvement gains typically range between $30 \%$ and $50 \%$.

An analysis of ventures just above and below the threshold, which removes the endogeneity of funding and many omitted variable biases, confirms the importance of receiving angel investments for the survival and growth of the venture. However, we do not see an impact of angel funding on accessing additional financing using this regression discontinuity approach. This may suggest that access to additional financing might often be a by-product of how angel funded firms grow but that this path may not be essential for venture success as we measure it. In addition, the result on follow-on venture funding might underline that in the time period we study, prior angel financing was not an essential prerequisite to accessing follow-on funding. However, the results overall suggest that the bundle of inputs that angel investors provide have a large and significant impact on the success and survival of the firms.

Finally, we also show that the impact of angel funding on firm outcomes would be overstated if we look at the full distribution of ventures that approach the angel groups, since there is a clear correlation between the quality of the start up and the level of interest. Simply restricting the treatment and control groups to a narrow range around the border discontinuity reduces the measured effects by a quarter from the raw correlations. This result reinforces the need to focus on the regression discontinuity approach we follow in this paper.

Thus, this paper provides a fresh look and new evidence at an essential question in entrepreneurial finance. It quantifies the positive impact that angel investors make to the 
companies that they fund in a way that simultaneously exploits novel, rich micro-data and addresses concerns about unobserved heterogeneity. Our work is closest in spirit to the papers in the entrepreneurial finance literature that focus on the investment process of venture capitalist. For example, Sorensen (2007) assesses the returns to being funded by different tiers of investors. Our work instead focuses on the margin of obtaining initial funding or not. Kaplan and Stromberg (2004) and Kaplan et al. (2009) examine the characteristics and dimensions that venture capitalists rely on when making investment decisions.

The plan of this paper is as follows. Section 1 reviews the angel group investment process. Section 2 introduces our angel investment data and describes our methodology. Section 3 introduces our outcomes data. Section 4 presents the analysis. The final section concludes the paper.

\section{The Angel Group Investment Process}

Angel investments — or equity investments by individuals into high-risk ventures — is an among the oldest of human commercial activities, dating back at least as far as the investment agreements recorded in the Code of Hammurabi circa 1790 B.C. For most of American economic history, angels represented the primary way in which entrepreneurs obtained high-risk capital for start-up businesses (e.g., Lamoreaux, Levenstein and Sokoloff, 2004), whether directly through individuals or through the offices that managed the wealth of high net worth individuals beginning in the last decades of the nineteenth century. Wealthy families such as the Phippses, Rockefellers, Vanderbilts, and Whitneys invested in and advised a variety of business enterprises, including the predecessor entities to AT\&T, Eastern Airlines, McDonald-Douglas, and W.R. Grace. 
The first formal venture capital firm, however, was not established until after World War II: American Research and Development (ARD) was formed by MIT President Karl Compton, Harvard Business School Professor Georges F. Doriot, and Boston business leaders in 1946. Over time, a number of the family offices transformed as well into stand-alone venture firms, including such groups as Bessemer, Venrock, and J.H. Whitney.

While angel investors have a long history, angel investment groups are a quite recent phenomenon. Beginning in the mid 1990s, angels began forming groups to collectively evaluate and invest in entrepreneurial ventures. These groups are seen as having several advantages by the angels. First, angels can pool their capital to make larger investments than they could otherwise. Second, each angel can invest smaller amounts in individual ventures, allowing participation in more opportunities and diversification of investment risks. They can also undertake costly due diligence of prospective investments as a group, reducing the burdens for individual members. Fourth, these groups are generally more visible to entrepreneurs and thus receive a superior deal flow. Finally, the groups frequently include some of the most sophisticated and active angel investors in the region, which results in superior decision-making.

The Angel Capital Association (ACA) lists 300 American groups in its database. The average ACA member angel group had 42 member angels and invested a total of \$1.94 million in 7.3 deals in 2007. Between 10,000 and 15,000 angels are believed to belong to angel groups in the U.S. ${ }^{2}$

Most groups follow a template that is more or less similar. Entrepreneurs typically begin the process by submitting to the group an application that may also include a copy of their business plan or executive summary. The firms, after an initial screening by the staff, are then

\footnotetext{
${ }^{2}$ Statistics are based on http://www.angelcapitalassociation.org/ (accessed February 15, 2010).
} 
invited to give a short presentation to a small group of members, followed by a question-andanswer session. Promising companies are then invited to present at a monthly meeting (often a weekday breakfast or dinner). The presenting companies that generate the greatest interest then enter a detailed due diligence process, although the extent to which due diligence and screening leads or follows the formal presentation varies across groups. A small group of angel members conduct this additional, intensive evaluation. If all goes well, this process results in an investment one to three months after the presentation. Figure 1 provides a detailed template for Tech Coast Angels (Sudek et al. 2008).

\section{Angel Group Data and Empirical Methodology}

This section jointly introduces our data and empirical methodology. The discussion is organized around the two groups from which we have obtained large datasets. The unique features of each investment group, their venture selection procedures, and their data records require that we employ conceptually similar, but operationally different, techniques for identifying group-specific discontinuities. We commence with Tech Coast Angels, the larger of our two investment groups, and we devote extra time in this first data description to also convey our empirical approach and the biases it is meant to address. We then describe our complementary approach with CommonAngels and how we ultimately join the two groups together to analyze their joint behavior.

\subsection{Tech Coast Angels}

Tech Coast Angels is a large angel investment group based in southern California. They have over 300 angels in five chapters seeking high-growth investments in a variety of high-tech 
and low-tech industries. The group typically looks for funding opportunities of $\$ 1$ million or less. Additional details on this venture group are available at http://www.techcoastangels.com/.

Tech Coast Angels kindly provided us with access to their database regarding prospective ventures under explicit restrictions that the confidentiality of individual ventures and angels remain secure. For our study, this database was exceptional in that it allowed us to fully observe the deal flow of Tech Coast Angels. Our analysis considers ventures that approached Tech Coast Angels between 2001 and 2006. We thus mainly build upon data records that existed in early 2007. At this time, there were over 2500 ventures in the database. The database is also exceptional in that it has detailed information about many of the companies that are not funded by Tech Coast Angels.

We first document in Table 1 the distribution of interest from the angel investors across the full set of potential deals. This description sets the stage for identifying a narrower group of firms around a funding discontinuity that offers a better approach for evaluating the consequences of angel financing. Table 2 then evaluates the ex ante comparability of deals around the border, which is essential for the identification strategy.

The central variable for the Tech Coast Angel analysis is a count of the number of angels expressing interest in a given deal. This indication of interest does not represent a financial commitment, but instead expresses a belief that the venture should be pursued further by the group. The decision to invest ultimately depends upon a few angels taking the lead and championing the deal. While this strength of conviction is unobserved, we can observe how funding relates to obtaining a critical mass of interested angels.

Table 1 documents the distribution of deals and angel interest levels. The first three columns of Table 1 show $64 \%$ of ventures receive no interest at all. Moreover, $90 \%$ of all 
ventures receive interest by fewer than ten angels. This narrowing funnel continues until the highest bracket, where there are 44 firms that receive interest from 35 or more angels. The maximum observed interest is 191 angels. This funnel shares many of the anecdotal traits of venture funding — such as selecting a few worthy ventures out of thousands of business plansbut it is exceptionally rare to have the interest level documented consistently throughout the distribution and independent of actual funding outcomes.

The shape of this funnel has several potential interpretations. It may reflect heterogeneity in quality among companies that are being pitched to the angels. It could also reflect simple industry differences across ventures. For example, the average software venture may receive greater interest than a medical devices company if there are more angels within the group involved in the software industry. There could also be an element of herding around "hot deals". But independent of what exactly drives this investment behavior of angels, we want to explore whether there are discontinuities in interest levels such that small changes in angels expressing interest among otherwise comparable deals results in material shifts in funding probability.

The central idea behind this identification strategy is that angel interest in ventures does not map one-to-one into quality differences across ventures, which we verify empirically below. Instead, there is some randomness or noise in why some firms receive n votes and others receive $\mathrm{n}+1$. It is reasonable to believe that there are enough idiosyncrasies in the preferences and beliefs of angels so that the interest count does not present a perfect ranking of the quality of the underlying firms. Certainly, the $2 \%$ of ventures with 35 or more interested angels are not comparable to the $64 \%$ of ventures with zero interest. But we will show that ventures with 18 votes and 22 votes are much more comparable, except that the latter group is much more likely to be funded. 
We thus need to demonstrate two pieces. First, we need to identify where in the distribution do small changes in interest level lead to a critical mass of angels, and thus a substantial increase in funding probability. As Tech Coast Angels does not have explicit funding rules that yield a mandated cut-off, we must identify from observed behavior where de facto breaks exist. We then need to show that deals immediately above and below this threshold appear similar at the time that they approached Tech Coast Angels.

To investigate the first part, the last column of Table 1 documents the fraction of ventures in each interest group that are ultimately funded by Tech Coast Angels. None of the ventures with zero interest are funded, whereas over $40 \%$ of deals in the highest interest category are. The rise in funding probability with interest level is monotonic with interest, excepting some small fluctuations at high interest levels.

There is a very stark jump in funding probability between interest levels of 15-19 angels and 20-24 angels, where the funded share increases from $17 \%$ to $38 \%$. This represents a distinct and permanent shift in the relationship between funding and interest levels. We thus identify this point as our discontinuity for Tech Coast Angels. In most of what follows, we discard deals that are far away from this threshold, and instead look around the border. We specifically drop the $90 \%$ of deals with fewer than ten interested angels, and we drop the 44 deals with very high interest levels. We designate our "above border" group as those ventures with interest levels of 20-34; our "below border" group is defined as ventures with 10-19 interest levels.

Having identified from the data the border discontinuity, we now verify the second requirement that ventures above and below the border look ex ante comparable except that they received funding from Tech Coast Angels. This step is necessary to assert that we have identified a quasi exogenous component to angel investing that is not merely reflecting underlying quality 
differences among the firms. Once established, a comparison of the outcomes of above border versus below border ventures will provide a better estimate of the role of angel financing in venture success as the quality differences inherent in the Table 1's distribution will be removed.

Before assessing this comparability, we make two sample adjustments. First, to allow us to later jointly analyze our two investment groups, we restrict the sample to ventures that approached Tech Coast Angels in the 2001-2006 period. This restriction also allows us a minimum horizon of four years for measuring outcomes. Second, we remove cases where the funding opportunity is withdrawn from consideration by the venture itself. These withdrawn deals are mainly due to ventures being funded by venture capital firms (i.e., the venture was courting multiple financiers simultaneously). As these deals do not fit well into our conceptual experiment of the benefits and costs of receiving or being denied angel funding, it is best to omit them from the sample. Our final sample includes 87 firms from Tech Coast Angels, with 46 ventures being above the border and 41 below. 45 of the 87 ventures are funded by Tech Coast Angels.

Table 2 shows that the characteristics of ventures above and below the funding threshold are very similar to one another ex ante. If our empirical approach is correct, the randomness in how localized interest develops will result in the observable characteristic of firms immediately above and below the threshold not being statistically different. Table 2 documents this comparability across a number of venture characteristics. Columns 2 and 3 present the means of the above border and below border groups, respectively. The fourth column tests for the equality of the means, and the t-tests allow for unequal variance.

The two border groups are very comparable in terms of venture traits, industries, and venture stages. The first four rows show that basic characteristics like the amount of funding 
requested, the documents provided by the venture to the angels, and the firm's number of managers and employees are not materially different for the firms above and below the discontinuity. The same is true for industry composition and stage of the business (e.g., is the firm in the idea stage, in its initial marketing and product development stage, or already revenue generating). For all of these traits, the null hypothesis that the two groups are similar is not rejected.

While there are no observable differences in the characteristics of the ventures in the first three panels, the fourth panel of Table 2 shows that there are significant differences in how angels engage with ventures above and below the cut-off. With just a small adjustment in interest levels, angels assemble many more documents regarding the venture (evidence of due diligence), have more discussion points in their database about the opportunity, and ultimately are $60 \%$ more likely to fund the venture. All of these differences are statistically significant.

\subsection{CommonAngels}

CommonAngels is the leading angel investment group in Boston, Massachusetts. They have over 70 angels seeking high-growth investments in high-tech industries. The group typically looks for funding opportunities between $\$ 500$ thousand and $\$ 5$ million. Additional details on this venture group are available at http://www.commonangels.com.

CommonAngels kindly provided us with access to their database regarding prospective ventures under explicit restrictions that the confidentiality of individual ventures and angels remain secure. The complete database for CommonAngels as of early 2007 contains over 2000 ventures. The funnel process is again such that a small fraction of ventures receive funding. 
Unlike the Tech Coast Angels data, however, CommonAngels does not record interest for all deals. We thus cannot explicitly construct a distribution similar to Table 1 .

CommonAngels does, however, conduct a paper-based poll of members following pitches at its monthly breakfast meetings. Most importantly, attending angels give the venture an overall score. Angels also provide comments about ventures and potential investments they might make in the company. Figure 2 provides a recent evaluation sheet. We focus on the overall score provided by angels for the venture as this metric is collected on a consistent basis throughout the sample period.

CommonAngels provided us with the original ballots for all pitches between 2001 and 2006. After dropping two poor quality records, our sample has 63 pitches in total. One potential approach would be to order deals by the average interest levels of angels attending the pitch. We find, however, that the information content in this measure is limited. Instead, the data strongly suggest that the central funding discontinuity exists around the share of attending angels that award a venture an extremely high score. During the six years covered, CommonAngels used both a five and ten point scale. It is extremely rare that an angel awards a perfect score to a pitch. The breaking point for funding instead exists around the share of attending angels that award the pitch $90 \%$ or more of the maximum score (that is, 4.5 out of 5,9 out of 10 ). This is close in spirit to the dichotomous expression of interest in the Tech Coast Angels database.

Some simple statistics describe the non-linear effect. Of the 63 pitches, 14 ventures receive a $90 \%$ or above score from at least one angel; no deal receives such a score from more than $40 \%$ of attending angels. Of these 14 deals, 7 deals are ultimately funded by CommonAngels. Of the 49 other deals, only 11 are funded. This stark discontinuity is not present when looking at lower cut-offs for interest levels. For example, all but 12 ventures 
receive at least one vote that is $80 \%$ of the maximum score (that is, 4 out of 5,8 out of 10 ). There is further no material difference in funding probability based upon receiving more or fewer $80 \%$ votes. The same applies to lower cut-offs for interest levels.

We restrict the sample to the 43 deals that have at least $20 \%$ of the attending angels giving the presentation a score that is $80 \%$ of the maximum possible score or above. As a specific example, a venture is retained after presenting to a breakfast meeting of 30 angels if at least six of those angels score the venture as 8 out of 10 or higher. This step removes the weakest presentations and ventures. We then define our border groups based upon the share of attending angels that give the venture a score greater than or equal to $90 \%$ of the maximum possible score. To continue our example, a venture is considered above border if it garners six or more angels awarding the venture 9 out of 10 or better. A venture with only five angels at this extreme value is classified as below border.

While distinct, this procedure is conceptually very similar to the sample construction and culling undertaken with the Tech Coast Angels data. We only drop 20 Common Angel pitches that receive low scores, but that is because the selection into providing a formal pitch to the group itself accomplishes much of the pruning. With Tech Coast Angels, we drop 90\% of the potential deals due to low interest levels. We implicitly do the same with CommonAngels by focusing only on the 63 pitches out of over 2000 deals in the full database.

Our formal empirical analyses jointly consider Tech Coast Angels and CommonAngels. To facilitate this merger, we construct simple indicator variables for whether a venture is funded or not. We likewise construct an indicator variable for above and below the border discontinuity. We finally construct uniform industry measures across the groups. This pooling produces a regression sample of 130 ventures. 


\section{Outcome Data}

This section documents the data that we collect on venture outcomes. This is the most significant challenge for this type of project as we seek comparable data for both funded and unfunded ventures. In many cases, the prospective deals are small and recently formed, and may not even be incorporated. We develop three broad outcomes: venture survival, venture growth and performance as measured by web site traffic data, and subsequent financing events.

\subsection{Venture Survival}

Our simplest measure is firm survival as of January 2010. This survival date is a minimum of four years after the potential funding event with the angel group. We develop this measure through several data sources. We first directly contacted as many ventures as possible to learn their current status. Second, we looked for evidence of the ventures' operations in the CorpTech and VentureXpert databases. Finally, we examined every venture's web site if one exists. Existence of a web site is not sufficient for being alive, as some ventures leave a web site running after closing operations. We thus based our measurement on how recent various items like press releases were.

In several cases, ventures have been acquired prior to 2010. We coded whether the venture was alive or not through a judgment of the size of the acquisition. Ventures are counted as alive if the acquisition or merger was a successful exit that included major announcements or large dollar amounts. If the event was termed an "asset sale" or similar, we code the venture as not having survived. The results below are robust to simply dropping these cases. 


\subsection{Venture Performance and Web Site Traffic}

Our second set of metrics quantify whether ventures are growing and performing better in the period after the potential financing event. While we would ideally consider a range of performance variables like employment, sales, and product introductions, obtaining data on private, unfunded ventures is extremely challenging. A substantial number of these ventures do not have employees, which limits their coverage even in comprehensive datasets like the Census Bureau surveys. We are able to make traction, however, through web traffic records. To our knowledge, this is the first time that this measure has been employed in an entrepreneurial finance study.

We collected web traffic data from www.alexa.com, one of the largest providers of this type of information. Alexa collects its data primarily by tracking the browsing patterns of web users who have installed the Alexa Toolbar, a piece of software that attaches itself onto a user's Internet browser and records the user's web use in detail. According to the company, there are currently millions of such users. The statistics are then extrapolated from this user subset to the Internet population as a whole. The two 'building block' pieces of information collected by the toolbar are web reach and page views. Web reach is a measure of what percentage of the total number of Internet users visit a website in question, and page views measures how many pages, on average, they visit on that website. Multiple page views by the same user in the same day only count as one entry in the data. The two usage variables are then combined to produce a variable known as site rank, with the most visited sites like Yahoo and Google having lower ranks.

We collected web traffic data in the summer of 2008 and January 2010. We identify 91 of our 130 ventures in one of the two periods, and 58 ventures in both periods. The absolute level of web traffic and its rank are very dependent upon the specific traits and business models of 
ventures. This is true even within broad industry groups as degrees of customer interaction vary. Some venture groups may also wish to remain "under the radar" for a few years until they are ready for product launch or have obtained intellectual property protection for their work. Moreover, the collection method by Alexa may introduce biases for certain venture types. We thus consider the changes in web performance for the venture between the two periods. These improvements or declines are more generally comparable across ventures.

One variable simply compares the log ratio of the web rank in 2010 to that in 2008 . This variable is attractive in that it measures the magnitudes of improvements and declines in traffic. A limitation, however, is that it is only defined for ventures whose web sites are active in both periods. We thus also define a second outcome measure as an indicator variable for improved venture performance on the web. If we observe the web ranks of a company in both 2008 and 2010, the indicator variable takes a value of one if the rank in 2010 is better than that in 2008. If we only observe the company on the web in 2008 , we deem its web performance to have declined by 2010. Likewise, if we only observe a company in 2010, we deem its web performance to have improved. This technique allows us to consider all 91 ventures for which we observe web traffic at some point, while sacrificing the granularity of the other measure.

\subsection{Subsequent Financing Events}

Our final measures describe whether the venture received subsequent financing external to the angel group. We define this measure through data collected from CorpTech and VentureXpert, cross-checked with as many ventures directly as possible. We consider a simply indicator variable for a subsequent, external financing and a count of the number of financing rounds. 


\section{Results}

This section documents our empirical results. We first more closely examine the relationship between border investments and angel funding. We then compare the subsequent outcomes of funded ventures with non-funded ventures; we likewise compare above border ventures with those below the discontinuity.

\subsection{Border Discontinuities and Angel Funding}

Table 3 formally tests that there is a significant discontinuity in funding around the thresholds for the ventures considered by Tech Coast Angels and CommonAngels. The dependent variable is an indicator variable that equals one if the firm received funding and zero otherwise. The primary explanatory variable is an indicator variable for the venture being above or below the interest discontinuity.

Column 1 controls for angel group fixed effects, year fixed effects, and industry fixed effects. Year fixed effects are for the year that the venture approached the angel group. These regressions combine data from the two angel groups. Across these two groups, we have 130 deals that are evenly distributed above and below the discontinuity. We find that there is a statistically and economically significant relationship between funding likelihood and being above the border: being above the border increases funding likelihood by about $33 \%$. Clearly, the border line designation is not an identity or perfect rule, but it does signify a very strong shift in funding probability among ventures that are ex ante comparable as shown in Table 2 .

Column 2 shows similar results when we add year*angel group fixed effects. These fixed effects control for the secular trends of each angel group. The funding jump also holds for 
each angel group individually. Column 3 repeats the regression controlling for deal characteristics like firm size and number of employees at the time of the pitch. The sample size shrinks to 87 as we only have this information for Tech Coast Angel deals. But despite the smaller sample size, we still find a significant difference in funding probability. The magnitude of the effect is comparable to the full sample at $29 \%$. Unreported regressions find a groupspecific elasticity for CommonAngels of $0.45(0.21)$. These patterns further hold in a variety of unreported robustness checks. These results suggest that the identified discontinuities provide a reasonable identification strategy.

\subsection{The Impact of Funding on Firm Outcomes}

We now look at the relationship between funding and firm outcomes. In the first column of Table 4, we regress a dummy variable for whether the venture was alive in 2010 on the indicator for whether the firm received funding from the angel group. We control for angel group, year, and industry fixed effects. The coefficient on indicator variable is 0.27 and is statistically significant at the $1 \%$ level. Firms that received angel funding are $27 \%$ more likely to survive for at least 4 years.

Columns 2 through 5 repeat this regression specification for the other outcomes variables. Funded companies show improvements in web traffic performance. Funded ventures are $16 \%$ more likely to have improved performance, but this estimate is not precisely measured. On the other hand, our intensive measure of firm performance, the log ratio of web site ranks, finds a more powerful effect. Funded ventures show on average 39\% stronger improvements in web rank than unfunded ventures. 
Finally, we estimate whether angel funding promotes future funding opportunities. We only look at venture funding external to the angel group in question. Column 4 finds a very large effect: angel funding increases the likelihood of subsequent venture investment by $44 \%$. This relationship is very precisely measured. Column 5 also shows a positive relationship to a count of additional venture rounds. Funded firms have about 3.8 more follow-on funding rounds than those firms that did not get angel funding in the first place.

Of course, we cannot tell from this analysis whether angel-backed companies pursue different growth or investment strategies and thus have to rely on more external funding. Alternatively, the powerful relationships could reflect a supply effect where angel group investors and board members provide networks, connections, and introductions that help ventures access additional funding. We return this issue below after viewing our border discontinuity results.

\subsection{The Role of Sample Construction}

The results in Table 4 suggest an important association between angel funding and venture performance. In describing our data and empirical methodology, we noted several ways that our analysis differed from a standard regression. We first consider only ventures that approach our angel investors, rather than attempting to draw similar firms from the full population of business activity to compare to funded ventures. This step helps ensure ex ante comparable treatment and control groups in that all the ventures are seeking funding. Second, we substantially narrow even this distribution of prospective deals (illustrated in Table 1) until we have a group of funded and unfunded companies that are ex ante comparable (show in Table 2). 
This removes heterogeneous quality in the ventures that approach the angel investors. Finally, we introduce the border discontinuity to bring exogenous variation in funding outcomes.

Before proceeding to the border discontinuity, it is useful to gauge how much the second step - narrowing the sample of ventures to remove quality differences inherent in the selection funnel-influences our regression estimates. Table 5 presents this analysis for one outcome variable and the Tech Coast Angels data. We are restricted to only one outcome variable by the intense effort to build any outcomes data for unfunded ventures. The likelihood of receiving subsequent venture funding is the easiest variable to extend to the full sample.

The first column repeats a modified, univariate form of Column 4 in Table 4 with just the Tech Coast Angels sample. The elasticities are very similar. The second column expands the sample to include 2385 potential ventures in the Tech Coast Angels database. The elasticity increases $25 \%$ to 0.56 . The difference in elasticities between the two columns demonstrates the role of sample construction in assessing angel funding and venture performance. The narrower sample provides a more comparable control group. Our rough estimate of the bias due to not controlling for heterogeneous quality is thus about a quarter of the true association.

\subsection{Border Discontinuities and Firm Outcomes}

Table 6 considers venture outcomes and the border discontinuity. Even with eliminating observable heterogeneity through sample selection, the results in Table 4 are still subject to the criticism that ventures are endogenously funded. Omitted variables may also be present. Looking above and below the funding discontinuity helps us to evaluate whether the ventures that looked ex ante comparable, except in their probability of being funded, are now performing differently. 
This test provides a measure of exogeneity to the relationship between angel financing and venture success.

Table 6 has the same format as Table 5; the only difference is that the explanatory variable is the indicator variable for being above the funding border. The results are similar in direction and magnitude for the first three outcomes, although the coefficients in Tables 5 and 6 are not directly comparable in a strict sense. Being above the border is associated with stronger chances for survival and better operating performance as measured by web site traffic. This comparability indicates that endogeneity in funding choices and omitted variable biases are not driving these associations for the impact of angel financing.

On the other hand, the last two columns show no relationship between being above the border discontinuity and improved funding prospects in later years. Our experiment thus does not confirm that angel financing leads to improved future investment flows to portfolio companies. This may indicate the least squares association between current financing and future financing reflects the investment and growth strategies of the financiers, but that this path is not necessary for venture success as measured by our outcome variables. This interpretation, however, should be treated with caution as we are not able to measure a number of outcomes that would be of interest (e.g., the ultimate value of the venture at exit).

\section{Conclusions and Interpretations}

The results of this study, and our border analysis in particular, suggest that angel investments improve entrepreneurial success. By looking above and below the discontinuity in a restricted sample, we remove the most worrisome endogeneity problems and the sorting between ventures and investors. We find that the localized increases in interest by angels at break points, 
which are clearly linked to obtaining critical mass for funding, are associated with discrete jumps in future outcomes like survival and stronger web traffic performance.

Our evidence regarding the role of angel funding for access to future venture financing is more mixed. The latter result could suggest that start-up firms during that time period had a number of funding options and thus could go to other financiers when turned down by our respective angel groups. Angel funding per se was not central in whether the firm obtained follow-on financing at a later point. However, angel funding by one of the groups in our sample does positively affect the long run survival and web traffic of the start-ups. We do not want to push this asymmetry too far, but one might speculate that access to capital per se is not the most important value added that angel groups bring. Our results suggest that some of the "softer" features, such as their mentoring or business contacts, may help new ventures the most.

Overall we find that the interest levels of angels at the stages of the initial presentation and due diligence are predictive of investment success. However, additional screening and evaluation do not substantially improve the selection and composition of the portfolio further. These findings suggest that the selection and screening process is efficient at sorting proposals into approximate bins: complete losers, potential winners, and so on. The process has natural limitations, however, in further differentiating among the potential winners (e.g., Kerr and Nanda, 2009).

At the same time, this paper has important limitations. Our experiment does not allow us to identify the costs to ventures of angel group support (e.g., Hsu, 2004), as equity positions in the counterfactual, unfunded ventures are not defined. We thus cannot evaluate whether taking the money was worth it from the entrepreneur's perspective after these costs are considered. On a similar note, we have looked at just a few of the many angel investment groups that are active in 
the US. Our groups are professionally organized and managed, and it is important for future research to examine a broader distribution of investment groups and their impact for venture success. This project demonstrates that angel investments are important and also offer an empirical foothold for analyzing many important questions in entrepreneurial finance 


\section{References}

Admati, A., and Pfleiderer, P. 1994. Robust financial contracting and the role for venture capitalists. Journal of Finance 49, 371-402.

Berglöf, E. 1994. A control theory of venture capital finance. Journal of Law, Economics, and Organizations 10, 247-67.

Bergemann, D., and Hege, U. 1998. Venture capital financing, moral hazard, and learning. Journal of Banking and Finance 22, 703-35.

Chemmanur, T., Krishnan, K., and Nandy, D. 2009. How does venture capital financing improve efficiency in private firms? a look beneath the surface. Unpublished working paper, Center for Economic Studies.

Cherenko, S., and Sunderam, A. 2009. The real consequences of market segmentation. Unpublished working paper, Harvard University.

Cornelli, F., and Yosha, O. 2003. Stage financing and the role of convertible debt. Review of Economic Studies 70, 1-32.

Goldfarb, B., Hoberg, G., Kirsch, D., and Triantis, A. 2007. Are angels preferred series a investors? Unpublished working paper, University of Maryland.

Hellmann, T. 1998. The allocation of control rights in venture capital contracts. RAND Journal of Economics 29, 57-76.

Hellmann, T., and Puri, M. 2000. The interaction between product market and financing strategy: the role of venture capital. Review of Financial Studies 13, 959-84.

Hsu, D. 2004. What do entrepreneurs pay for venture capital affiliation? Journal of Finance 59, $1805-44$.

Kaplan, S., and Strömberg, P. 2004. Characteristics, contracts, and actions: evidence from venture capitalist analyses. Journal of Finance 59, 2177-210.

Kaplan, S., Sensoy, B., and Strömberg, P. 2009. Should investors bet on the jockey or the horse? evidence from the evolution of firms from early business plans to public companies. Journal of Finance 64, 75-115.

Kerr, W., and Nanda, R. 2009. Democratizing entry: banking deregulations, financing constraints, and entrepreneurship. Journal of Financial Economics 94, 124-49.

Kortum, S., and Lerner, J. 2000. Assessing the contribution of venture capital to innovation. RAND Journal of Economics 31, 674-92. 
Lamoreaux, N., Levenstein, M., and Sokoloff, K. 2004. Financing invention during the second industrial revolution: Cleveland, Ohio, 1870-1920. Working paper no. 10923, National Bureau of Economic Research.

Lee, D., and Lemieux, T. 2009. Regression discontinuity designs in economics. Working paper no. 14723, National Bureau of Economic Research.

Mollica, M., and Zingales, L. 2007. The impact of venture capital on innovation and the creation of new businesses. Unpublished working paper, University of Chicago.

Puri, M., and Zarutskie, R. 2008. On the lifecycle dynamics of venture-capital- and non-venturecapital-financed firms. Unpublished working paper, Center for Economic Studies.

Rauh, J. 2006. Investment and financing constraints: evidence from the funding of corporate pension plans. Journal of Finance 61, 31-71.

Samila, S., and Sorenson, O. 2010. Venture capital, entrepreneurship and economic growth. Review of Economics and Statistics, forthcoming.

Shane, S. 2008. The importance of angel investing in financing the growth of entrepreneurial ventures. Unpublished working paper, U.S. Small Business Administration, Office of Advocacy.

Sorensen, M. 2007. How smart is the smart money? a two-sided matching model of venture capital. Journal of Finance 62, 2725-62.

Sudek, R., Mitteness, C., and Baucus, M. 2008. Betting on the horse or the jockey: the impact of expertise on angel investing. Academy of Management Best Paper Proceedings. 


\section{Figure 1: Tech Coast Angels Investment Process}

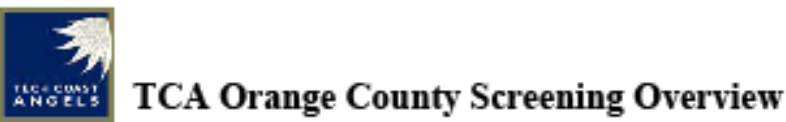

Welcome to the \#1 Angel network in the US. We are pleased you are attending an Orange County screening session. The screening process is an important part of the TCA process. Typically, we have over 300 companies per year apply over the web for TCA funding. Approximately one third of these companies make it to the screening process which you are about to participate in. Although each year varies, we typically fund between 10 and 20 companies per year. TCA consists of 4 chapters, each facilitating the first three steps of the deal flow process a little differently. The overall deal flow process for TCA consists of 7 steps as follows:

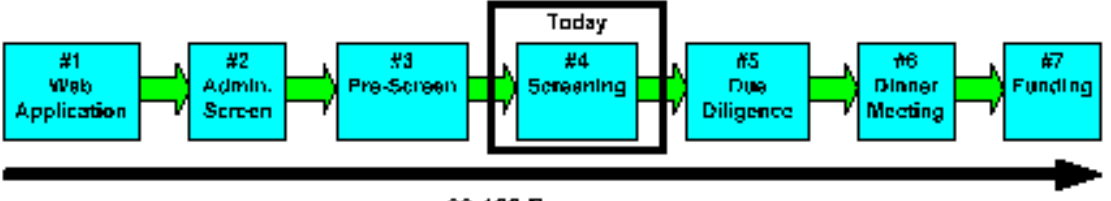

60-120 Days

1. Web Application - Entrepreneurs apply to TCA on the Internet. This process includes filling out a 4 page overview of their startup venture.

2. Admin Screen - TCA staff perform a quick screen on the application to insure it is within the target area for a TCA venture. For instance, we typically fund between $\$ 250,000$ and $\$ 1$ million. If a company is seeking outside this range, typically they are not moved forward to pre-screen.

3. Pre-Screen - In Orange County entrepreneurs present a brief overview of their company to 3-7 TCA members. This includes 5 minutes of presentation and 25 minutes of informal questions and discussion with the TCA members. At the conclusion of this session, the prospective company is moved to screening, or given feedback why they may not be a good fit for TCA.

4. Screening - Typically 3 companies present at a screening. This consists of 15 minutes of PowerPoint and 15 minutes of Q\&A. After the Q\&A, we ask the entrepreneurs to leave the room and we discuss the company in private (typically it takes 10-15 minutes). The entrepreneurs are invited back into the room, and a designated member provides quick feedback. Typically, the companies present at all 5 chapters. Therefore, it is possible for a company to get little interest at one chapter, but enough interest at another chapter that will allow it to move forward to due diligence. In Orange County we utilize a moderator to facilitate the sessions. This is intended to help balance questions for our members such that a member will not dominate the Q\&A time. If you are a prospective member you are welcome to ask questions during the Q\&A portion of the presentation.

5. Due Diligence - A due diligence team is formed based on the number of interested members who signed up during the screening. A deal lead steps forward and helps coordinate the due diligence activities. Due diligence consists of verifying representations by the venture, customers, agreements, references, backgrounds, etc. The results of the due diligence process are posted on the TCA website (members only section), and if the results are positive, the venture moves forward to dinner meetings.

6. Dinner Meeting - Companies that pass due diligence present at monthly dinner meetings at each chapter. This allows them to get in front of members who might not have seen them at screening or were involved in the due diligence process. This is the opportunity for the entrepreneurs to gamer enough interest by members to secure funding.

7. Funding - Funding occurs after there has been enough interest generated through dinner meetings and internal communication from the entrepreneur and deal lead. Members invest in deals individually, thus only a small percentage of members need to participate for the venture to secure funding. Typically, the minimum investment amount $\$ 25,000$.

@2008 Richard Sudek 
Figure 2: CommonAngels Pitch Evaluation Sheet

Cenfidential when Completed

[lnvestor Name]

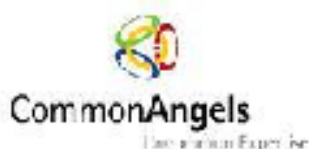

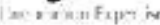

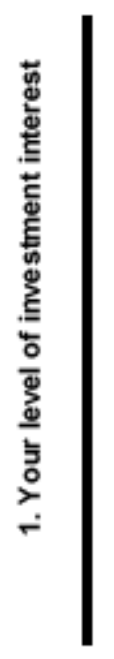

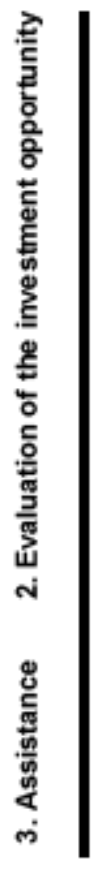

How much?

Positive factors:

Negative factors:

How I can Help:

$\square$ Diligence team

Overall Investment Potential:

$\begin{array}{lllll}1 & 2 & 3 & 4\end{array}$

$\begin{array}{lll}\text { Are you interested in investing? } & \text { YES NO }\end{array}$

POSSIBLY (please comment)

$\$$

Comments andlor kev issues for due diliaence:

$\square$ Contacts/introductions 
Table 1: Angel group selection funnel

\begin{tabular}{cccc}
$\begin{array}{c}\text { Angel group } \\
\text { interest level }\end{array}$ & $\begin{array}{c}\text { Number of } \\
\text { ventures }\end{array}$ & $\begin{array}{c}\text { Cumulative } \\
\text { share of ventures }\end{array}$ & $\begin{array}{c}\text { Share funded } \\
\text { by angel group }\end{array}$ \\
\hline 0 & 1640 & $64 \%$ & 0.000 \\
$1-4$ & 537 & $84 \%$ & 0.007 \\
$5-9$ & 135 & $90 \%$ & 0.037 \\
$10-14$ & 75 & $93 \%$ & 0.120 \\
$15-19$ & 52 & $95 \%$ & 0.173 \\
$20-24$ & 42 & $96 \%$ & 0.381 \\
$25-29$ & 33 & $97 \%$ & 0.303 \\
$30-34$ & 21 & $98 \%$ & 0.286 \\
$35+$ & 44 & $100 \%$ & 0.409
\end{tabular}

Notes: Table documents the selection funnel for Tech Coast Angels. The vast majority of ventures proposed to Tech Coast Angels receive very little interest, with $90 \%$ of plans obtaining the interest of fewer than ten angels. A small fraction of ventures obtain extremely high interest levels with a maximum of 191 angels expressing interest. We identify an interest level of 20 angels as our border discontinuity. Our "below border" group consists of ventures receiving 10-19 interested angels. Our "above border" group consists of ventures receiving 20-34 interested angels. 


\section{Table 2: Comparison of groups above and below border discontinuity}

\begin{tabular}{lccc}
\hline \multicolumn{1}{c}{$\begin{array}{c}\text { Traits of ventures above and } \\
\text { below border discontinuity }\end{array}$} & $\begin{array}{c}\text { Above border } \\
\text { ventures }\end{array}$ & $\begin{array}{c}\text { Below border } \\
\text { ventures }\end{array}$ & $\begin{array}{c}\text { Two-tailed t-test } \\
\text { for equality of means }\end{array}$ \\
\hline Basic characteristics & 1573 & 1083 & 0.277 \\
Financing sought (\$ thousands) & 3.0 & 2.5 & 0.600 \\
Documents from company & 5.8 & 5.4 & 0.264 \\
Management team size & 13.4 & 11.2 & 0.609 \\
Employee count & & & \\
Primary industry (\%) & 23.9 & 29.3 & 0.579 \\
Biopharma and healthcare & 15.2 & 17.1 & 0.817 \\
Computers, electronics, and measurement & 39.1 & 39.0 & 0.992 \\
Internet and e-commerce & 21.7 & 14.6 & 0.395 \\
Other industries & & & 0.936 \\
Company stage (\%) & 2.2 & 2.4 & 0.279 \\
Good idea & 34.8 & 46.3 & 0.272 \\
Initial marketing and product development & 63.0 & 51.2 & \\
Revenue generating & & & 0.004 \\
Angel group decisions & 10.5 & 5.1 & 0.002 \\
Documents by angel members & 12.0 & 6.7 & 0.025 \\
Discussion items by angel members & 63.0 & 39.0 & \\
Share funded & & & \\
\hline
\end{tabular}

Notes: Table demonstrates the ex ante comparability of ventures above and below the border discontinuity. Columns 2 and 3 present the means of the above border and below border groups, respectively. The fourth column tests for the equality of the means, and the t-tests allow for unequal variance. The first three panels show that the two groups are very comparable in terms of venture traits, industries, and venture stage. The first row tests equality for log value of financing sought. For none of these ex ante traits are the groups statistically different from each other. The two groups differ remarkably, however, in the likelihood of receiving funding. This is shown in the fourth panel. Comparisons of the subsequent performance of these two groups thus offers a better estimate of the role of angel financing in venture success as the quality heterogeneity of ventures inherent in the full distribution of Table 1 is removed. 
Table 3: Border discontinuity and venture funding by angel groups

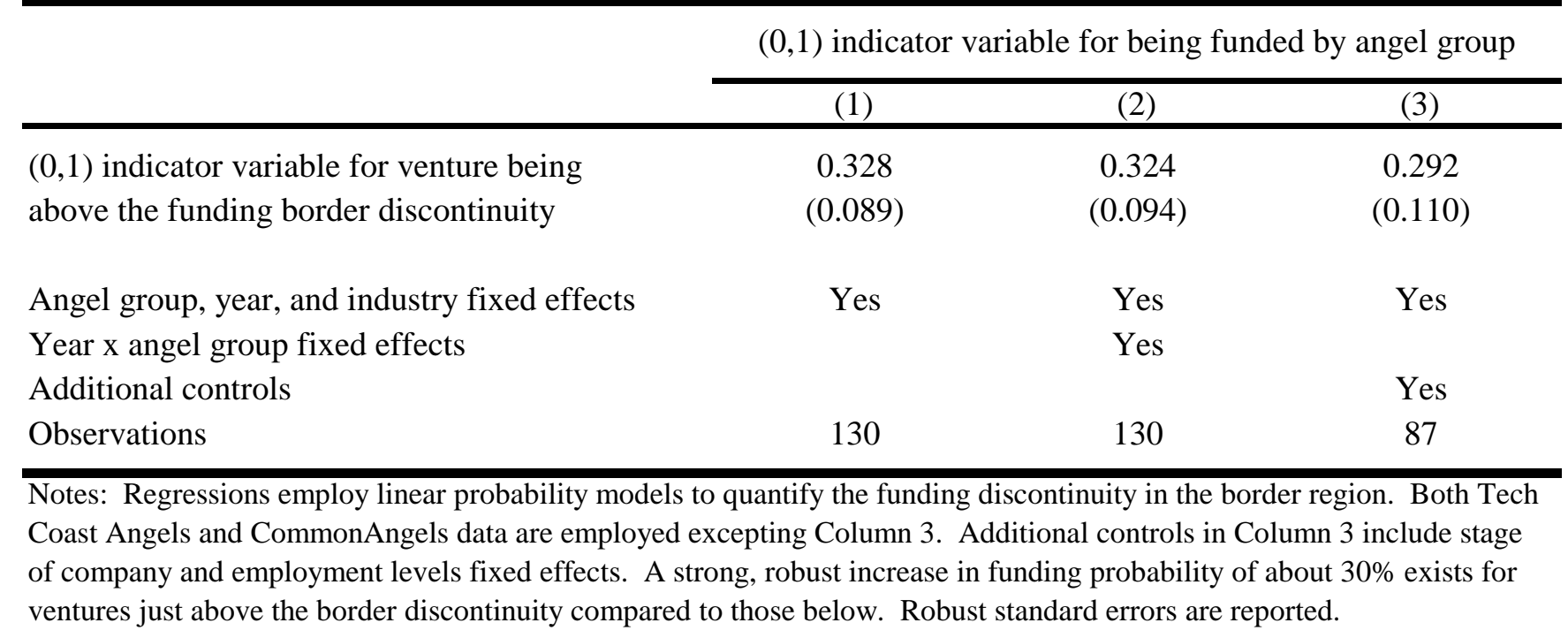


Table 4: Analysis of angel group financing and venture performance

\begin{tabular}{|c|c|c|c|c|c|}
\hline & $\begin{array}{l}(0,1) \text { indicator } \\
\text { variable for } \\
\text { venture being } \\
\text { alive in January } \\
2010\end{array}$ & $\begin{array}{l}(0,1) \text { indicator } \\
\text { variable for } \\
\text { improved web } \\
\text { rank from } 2008 \\
\quad \text { to } 2010\end{array}$ & $\begin{array}{c}\text { Log ratio of } \\
2010 \text { web rank } \\
\text { to } 2008 \text { rank } \\
\text { (negative values } \\
\text { are improvements) }\end{array}$ & $\begin{array}{l}(0,1) \text { indicator } \\
\text { variable for } \\
\text { receiving later } \\
\text { funding external } \\
\text { to angel group }\end{array}$ & $\begin{array}{c}\text { Count } \\
\text { of subsequent } \\
\text { venture financing } \\
\text { rounds external } \\
\text { to angel group }\end{array}$ \\
\hline & (1) & (2) & (3) & (4) & (5) \\
\hline $\begin{array}{l}(0,1) \text { indicator variable for venture } \\
\text { funding being received from angel group }\end{array}$ & $\begin{array}{c}0.276 \\
(0.082)\end{array}$ & $\begin{array}{c}0.162 \\
(0.107)\end{array}$ & $\begin{array}{l}-0.389 \\
(0.212)\end{array}$ & $\begin{array}{c}0.438 \\
(0.083)\end{array}$ & $\begin{array}{c}3.894 \\
(1.229)\end{array}$ \\
\hline $\begin{array}{l}\text { Angel group, year, and industry fixed effects } \\
\text { Observations }\end{array}$ & $\begin{array}{l}\text { Yes } \\
130\end{array}$ & $\begin{array}{l}\text { Yes } \\
91\end{array}$ & $\begin{array}{c}\text { Yes } \\
58\end{array}$ & $\begin{array}{l}\text { Yes } \\
130\end{array}$ & $\begin{array}{l}\text { Yes } \\
130\end{array}$ \\
\hline
\end{tabular}

Notes: Linear regressions quantify the relationship between funding and venture outcomes. Both Tech Coast Angels and CommonAngels data for 2001-2006 are employed in all regressions. Differences in sample sizes across columns are due to the availability of outcome variables. The first column tests whether the venture is alive in 2010. The second and third columns test for improved venture performance through web site traffic data from 2008 to 2010 . Column 2 is an indicator variable for improved performance, while Column 3 gives log ratios of web traffic (a negative value indicates better performance). The last two columns test whether the venture received subsequent financing outside of the angel group by 2010. Across all of these outcomes, funding by an angel group is associated with stronger subsequent venture performance. Robust standard errors are reported. 
Table 5: Border samples versus full samples

\begin{tabular}{|c|c|c|}
\hline \multirow[t]{2}{*}{$\begin{array}{l}\text { Outcome variable is }(0,1) \text { indicator } \\
\text { variable for receiving later funding } \\
\text { external to angel group } \\
\text { (see Column } 4 \text { of Table } 4)\end{array}$} & $\begin{array}{l}\text { Simple TCA } \\
\text { univariate } \\
\text { regression with } \\
\text { border sample }\end{array}$ & $\begin{array}{l}\text { Full TCA } \\
\text { univariate } \\
\text { regression with } \\
\text { complete sample }\end{array}$ \\
\hline & (1) & (2) \\
\hline $\begin{array}{l}(0,1) \text { indicator variable for venture } \\
\text { funding being received from angel group }\end{array}$ & $\begin{array}{c}0.432 \\
(0.095)\end{array}$ & $\begin{array}{c}0.562 \\
(0.054)\end{array}$ \\
\hline Observations & 87 & 2385 \\
\hline \multicolumn{3}{|c|}{$\begin{array}{l}\text { Notes: Linear regressions quantify the role of sample construction in the relationship between } \\
\text { funding and venture outcomes. Column } 1 \text { repeats a modified, univariate form of the Column } 4 \text { in } \\
\text { Table } 4 \text { with just the Tech Coast Angels sample. Column } 2 \text { expands the sample to include all of } \\
\text { the potential ventures in the Tech Coast Angels database, similar to Table } 1 \text {. The difference in } \\
\text { elasticities between the two columns demonstrates the role of sample construction in assessing } \\
\text { angel funding and venture performance. The narrower sample provides a more comparable } \\
\text { control group. Robust standard errors are reported. }\end{array}$} \\
\hline
\end{tabular}


Table 6: Analysis of border discontinuity and venture performance

\begin{tabular}{|c|c|c|c|c|c|}
\hline & $\begin{array}{l}(0,1) \text { indicator } \\
\text { variable for } \\
\text { venture being } \\
\text { alive in January } \\
2010\end{array}$ & $\begin{array}{l}(0,1) \text { indicator } \\
\text { variable for } \\
\text { improved web } \\
\text { rank from } 2008 \\
\text { to } 2010\end{array}$ & $\begin{array}{c}\text { Log ratio of } \\
2010 \text { web rank } \\
\text { to } 2008 \text { rank } \\
\text { (negative values } \\
\text { are improvements) }\end{array}$ & $\begin{array}{l}(0,1) \text { indicator } \\
\text { variable for } \\
\text { receiving later } \\
\text { funding external } \\
\text { to angel group }\end{array}$ & $\begin{array}{c}\text { Count } \\
\text { of subsequent } \\
\text { venture financing } \\
\text { rounds external } \\
\text { to angel group }\end{array}$ \\
\hline & (1) & (2) & (3) & (4) & (5) \\
\hline $\begin{array}{l}(0,1) \text { indicator variable for venture being } \\
\text { above the funding border discontinuity }\end{array}$ & $\begin{array}{c}0.229 \\
(0.094)\end{array}$ & $\begin{array}{c}0.232 \\
(0.120)\end{array}$ & $\begin{array}{l}-0.382 \\
(0.249)\end{array}$ & $\begin{array}{c}0.106 \\
(0.100)\end{array}$ & $\begin{array}{l}-0.318 \\
(1.160)\end{array}$ \\
\hline $\begin{array}{l}\text { Angel group, year, and industry fixed effects } \\
\text { Observations }\end{array}$ & $\begin{array}{l}\text { Yes } \\
130\end{array}$ & $\begin{array}{l}\text { Yes } \\
91\end{array}$ & $\begin{array}{c}\text { Yes } \\
58\end{array}$ & $\begin{array}{l}\text { Yes } \\
130\end{array}$ & $\begin{array}{l}\text { Yes } \\
130\end{array}$ \\
\hline
\end{tabular}

Notes: See Table 4. Linear regressions quantify the relationship between the border discontinuity and venture outcomes. Companies above the border are more likely to be alive in 2010 and have improved web performance relative to companies below the border. These results are similar to the funding relationships in Table 4 . The border discontinuity in the last two columns, however, is not associated with increased subsequent financing events. 